\title{
Sensitivity to ampicillin, penicillin, and tetracyline of gonococci in Rotterdam
}

\author{
E. STOLZ,* H. G. F. ZWART, $†$ AND M. F. MICHEL $†$ \\ From the Dermatology Department ${ }^{\star}$ and the Bacteriological Laboratory† of the Medical Faculty of the \\ Erasmus University, Rotterdam
}

Published data on quantitative determinations of the sensitivity of gonococci to penicillin and tetracycline in the Netherlands are scarce. As far as we know quantitative determinations of the sensitivity to ampicillin of gonococci isolated there have never been published.

Data on the sensitivity of gonococci to penicillin have been published by Bakker, Esseveld, and Leiker (1960), Vermeer and Schaap, (1962), Heimans (1967), and Wols-van der Wielen (1971).

Heimans (1967) investigated the quantitative sensitivity to tetracycline $\mathrm{HCl}$ of 192 strains isolated in Amsterdam.

The present paper reports quantitative sensitivity determinations for ampicillin, penicillin, and tetracycline, carried out on gonococcal strains isolated from male and female civilians and from male and female seafaring personnel.

The results are compared with former data from the Netherlands and some other countries and correlations are given between the observed sensitivities for ampicillin and penicillin, tetracycline and ampicillin, and tetracycline and penicillin.

\section{Material and methods}

The investigation was carried out between October 18, 1971, and July 1, 1972.

The patients consisted of male and female civilians (MC and FC) and male and female seafaring personnel (MS and FS). When patients attended with a subsequent infection in the period under investigation, only the strain from the first infection was used for this investigation.

Material was collected with carbon-impregnated cotton-wool swabs. In women, material was taken from the cervix (C), the urethra (U), and the rectum (R), and in the period from February 1, 1972, to July 1, 1972, also from the vagina $(V)$. In men, material was taken from the urethra $(U)$, and if indicated prostatic fluid (P) and

Received for publication October 4, 1973

Address for reprints: E. Stolz, Dermatology Department, Erasmus University, Rotterdam, The Netherlands material from the rectum (R) were also investigated. Sometimes swabs from the tonsil/oropharynx $(T)$ were taken from both men and women. The swabs were placed in Stuart's transport medium, and inoculated on to a selective medium (Thayer and Martin, 1966) within $4 \mathrm{hrs}$.

The cultures were incubated at $37^{\circ} \mathrm{C}$. in a $\mathrm{CO}_{2}$-rich environment. If suspect colonies were found within 48 hrs, a Gram-preparation was made, the colonies were tested for oxidase activity, and sugar fermentations were carried out.

Sensitivities to ampicillin, penicillin, and tetracycline were determined by the agar dilution method (Ericsson and Sherris, 1971). The concentrations of ampicillin were in the range $0.005-0.64 \mu \mathrm{g} . / \mathrm{ml}$., those of penicillin in the range $0.0025-1.28 \mu \mathrm{g} . / \mathrm{ml}$., and those of tetracycline in the range 0.04 to $2.56 \mu \mathrm{g} . / \mathrm{ml}$.

Two-fold dilutions of antibiotic in water were incorporated in a medium consisting of GC medium base (Difco), haemoglobin (Difco), and Isovitalex (BBL), and distributed on to plates. A control without antibiotic was included in each series.

The organisms to be tested were freshly suspended in trypticase soy broth (BBL) to a density of $10^{6}-10^{7}$ V.U./ $\mathrm{ml}$. With a multipoint replicator, these suspensions were inoculated on to the plate series, resulting in spot inocula covering a circle of 4-6 mm. diameter and containing $10^{3}-10^{4}$ V.U.

In each run, three gonococcal strains and one Staphylococcus (Oxford strain) with known sensitivity for ampicillin, penicillin, and tetracycline were tested simultaneously.

After incubation (18-20 hrs) the minimum inhibitory concentration was determined by observing the lowest concentration of antibiotics in which bacterial growth was completely or almost completely inhibited, as judged by the naked eye. A haze of growth or a single colony was disregarded.

The results were recorded on optically readable forms. With the use of an IBM 1232 optical mark page-reader, the forms were converted into punched cards by means of a coupled IBM 534 card punch. With the assistance of the System Development Department of the Medical Faculty, use was made of an IBM 2780 terminal, connected via a permanent telephone line to an IBM 360 (model 65) computer system. 


\section{Results}

Altogether 1,016 cultures were positive; from these 959 strains were available for sensitivity determination.

The distribution of the positive cultures and the cultures on which sensitivity determinations could be performed (shown between brackets) among the groups of male and female civilians (MC and FC) and male and female seafaring personnel (MS and FS) and among the various sampling sites is shown in Table I.

The distribution of the MICs for the strains from the groups MC-Urethra (MCU), FC-Cervix (FCC), MS-Urethra (MSU), MC-Prostatic fluid (MCP), FC-Rectum (FCR), and FC-Vagina (FCV) are given in Table II.

TABLE I Distribution of positive cultures (total) and cultures for which sensitivity was determined (figures between brackets), by site of isolation and population group

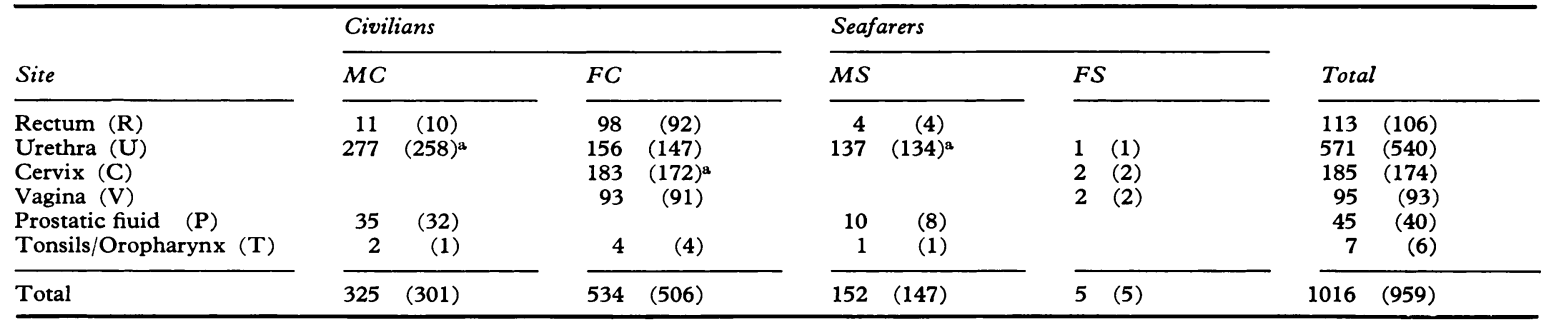

$\mathrm{MC}=$ male civilians

$\mathrm{FC}=$ female civilians

MS = male seafaring personnel

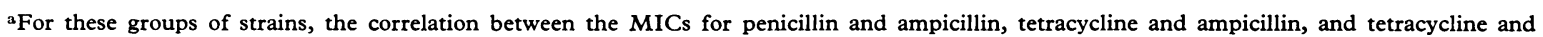
penicillin was determined (Tables IV to VII)

TABLE II Distribution of MICs (expressed as per cent. of total) for ampicillin, penicillin, and tetracycline in the $M C U, F C C, M S U, M C P, F C R, F C U$, and FCV strains. Number of strains tested shown in brackets

\begin{tabular}{|c|c|c|c|c|c|c|c|}
\hline$M I C(\mu g . / m l)$. & $\begin{array}{l}M C U^{\mathrm{a}} \\
(258)\end{array}$ & $\begin{array}{l}F C C^{\mathrm{a}} \\
(172)\end{array}$ & $\begin{array}{l}M S U^{a} \\
(134)\end{array}$ & $\begin{array}{l}M C P \\
(32)\end{array}$ & $\begin{array}{l}F C R \\
(92)\end{array}$ & $\begin{array}{l}F C U \\
(147)\end{array}$ & $\begin{array}{l}F C V \\
(91)\end{array}$ \\
\hline $\begin{array}{l}\text { Ampicillin } \\
0.005 \\
0.01 \\
0.02 \\
0.04 \\
0.08 \\
0.16 \\
0.32 \\
0.64\end{array}$ & $\begin{array}{r}0 \cdot 4 \\
5 \cdot 8 \\
19 \cdot 8 \\
25 \cdot 6 \\
8 \cdot 1 \\
9 \cdot 3 \\
16 \cdot 3 \\
14 \cdot 7\end{array}$ & $\begin{array}{r}7 \cdot 0 \\
22 \cdot 7 \\
25 \cdot 0 \\
10 \cdot 5 \\
8 \cdot 1 \\
11 \cdot 6 \\
15 \cdot 1\end{array}$ & $\begin{array}{r}2.2 \\
9.0 \\
10.4 \\
9.7 \\
13.4 \\
24.6 \\
30.6\end{array}$ & $\begin{array}{r}6 \cdot 3 \\
37 \cdot 5 \\
25 \cdot 0 \\
6 \cdot 3 \\
9 \cdot 4 \\
3 \cdot 1 \\
12 \cdot 5\end{array}$ & $\begin{array}{r}4 \cdot 3 \\
20 \cdot 7 \\
28 \cdot 3 \\
12 \cdot 0 \\
5 \cdot 4 \\
17 \cdot 4 \\
12 \cdot 0\end{array}$ & $\begin{array}{r}4 \cdot 1 \\
24 \cdot 5 \\
23 \cdot 1 \\
12 \cdot 2 \\
5 \cdot 4 \\
19 \cdot 0 \\
11 \cdot 6\end{array}$ & $\begin{array}{r}5 \cdot 5 \\
30 \cdot 8 \\
16 \cdot 5 \\
12 \cdot 1 \\
8 \cdot 8 \\
19 \cdot 8 \\
6.6\end{array}$ \\
\hline $\begin{array}{l}\text { Penicillin } \\
0.0025 \\
0.005 \\
0.01 \\
0.02 \\
0.04 \\
0.08 \\
0.16 \\
0.32 \\
0.64 \\
1.28\end{array}$ & $\begin{array}{r}7 \cdot 0 \\
21 \cdot 3 \\
21 \cdot 7 \\
6 \cdot 2 \\
5 \cdot 4 \\
8 \cdot 1 \\
8 \cdot 9 \\
10 \cdot 1 \\
6 \cdot 6 \\
4 \cdot 7\end{array}$ & $\begin{array}{r}5 \cdot 2 \\
26 \cdot 2 \\
26 \cdot 2 \\
4 \cdot 7 \\
2 \cdot 9 \\
6 \cdot 4 \\
11 \cdot 6 \\
9 \cdot 3 \\
6 \cdot 4 \\
1 \cdot 2\end{array}$ & $\begin{array}{r}3 \cdot 0 \\
7 \cdot 5 \\
9 \cdot 7 \\
6 \cdot 0 \\
6 \cdot 7 \\
11 \cdot 2 \\
6 \cdot 0 \\
15 \cdot 7 \\
26 \cdot 1 \\
8 \cdot 2\end{array}$ & $\begin{array}{l}18 \cdot 8 \\
40.6 \\
15 \cdot 6 \\
- \\
- \\
3 \cdot 1 \\
3 \cdot 1 \\
9 \cdot 4 \\
6 \cdot 3 \\
3.1\end{array}$ & $\begin{array}{r}7 \cdot 6 \\
25 \cdot 0 \\
23 \cdot 9 \\
5 \cdot 4 \\
4 \cdot 3 \\
6 \cdot 5 \\
13 \cdot 0 \\
9 \cdot 8 \\
3 \cdot 3 \\
1 \cdot 1\end{array}$ & $\begin{array}{r}7 \cdot 0 \\
21 \cdot 3 \\
21 \cdot 7 \\
6 \cdot 2 \\
5 \cdot 4 \\
8 \cdot 1 \\
8 \cdot 9 \\
10 \cdot 1 \\
6 \cdot 6 \\
4 \cdot 7\end{array}$ & $\begin{array}{r}3 \cdot 3 \\
24 \cdot 2 \\
33 \cdot 0 \\
3 \cdot 3 \\
1 \cdot 1 \\
4 \cdot 4 \\
13 \cdot 2 \\
7 \cdot 7 \\
8 \cdot 8 \\
1 \cdot 1\end{array}$ \\
\hline $\begin{array}{l}\text { Tetracycline } \\
0.04 \\
0.08 \\
0.16 \\
0.32 \\
0.64 \\
1.28 \\
2.56\end{array}$ & $\begin{array}{r}0 \cdot 8 \\
5 \cdot 4 \\
43 \cdot 8 \\
16 \cdot 3 \\
16 \cdot 7 \\
15 \cdot 1 \\
1 \cdot 9\end{array}$ & $\begin{array}{r}-7 \cdot 0 \\
46 \cdot 5 \\
18 \cdot 6 \\
15 \cdot 7 \\
10 \cdot 5 \\
1 \cdot 7\end{array}$ & $\begin{array}{r}0.7 \\
1.5 \\
17 \cdot 2 \\
14.9 \\
26 \cdot 9 \\
32.8 \\
6.0\end{array}$ & $\begin{array}{c}- \\
3 \cdot 1 \\
59 \cdot 4 \\
12 \cdot 5 \\
15 \cdot 6 \\
9 \cdot 4 \\
-\end{array}$ & $\begin{array}{r}1 \cdot 1 \\
6 \cdot 1 \\
52 \cdot 5 \\
16 \cdot 3 \\
14 \cdot 1 \\
8 \cdot 8 \\
1 \cdot 1\end{array}$ & $\begin{array}{r}- \\
6 \cdot 8 \\
44 \cdot 9 \\
17 \cdot 7 \\
18 \cdot 4 \\
10 \cdot 2 \\
2 \cdot 2\end{array}$ & $\begin{array}{r}- \\
2 \cdot 2 \\
44 \cdot 0 \\
20 \cdot 9 \\
17 \cdot 6 \\
13 \cdot 2 \\
2 \cdot 2\end{array}$ \\
\hline
\end{tabular}

${ }^{a}$ For these groups of strains, the correlation between the MICs for penicillin and ampicillin, tetracycline and ampicillin, and tetracycline and penicillin has been calculated (Tables IV to VII) 
No significant difference was found between the distribution of sensitivities for MCU compared with MCP, and for FCC compared with FCR, FCU, and FCV at a probability level of 0.05 ( $\chi^{2}$ test).

In our series, gonococci taken from different sites showed a different sensitivity pattern (more than one antibiotic concentration difference) in less than one patient in 200. Moreover, it was found that, if the urethra is taken as the basic site of diagnosis for men and the cervix for women, the detection of gonococci in other sites contributed only slightly to the detection of patients with gonorrhoea (Table III). Also the numbers involved were so small that they had little influence on the distribution of the MICs.

For these reasons, it was decided to determine the correlation between the MICs for penicillin and ampicillin, tetracycline and ampicillin, and tetracycline and penicillin for the MCU, FCC, and MSU strains only.

Our impression that there was a relationship between the sensitivities of the gonococci for penicillin and ampicillin, tetracycline and ampicillin, and tetracycline and penicillin was 'confirmed' (i.e. not contradicted) by Spearman's rank correlation test. This test was carried out on all three groups of strains (MCU, FCC, and MSU), and the probability value was less than 0.01 in all cases.
In Tables IV, V, and VI, the MICs for penicillin and ampicillin, tetracycline and ampicillin, and tetracycline and penicillin in the MCU strains are set out in correlation Tables.

The rank correlation coefficient is given in each case. Similar correlation Tables were made for the FCC and MSU strains, and the rank correlation coefficients were calculated. The nine rank correlation coefficients are given together in Table VII.

\section{Discussion}

It has been found that a representative picture of the MIC distribution for ampicillin, penicillin, and tetracycline in our patient groups $\mathrm{MC}, \mathrm{FC}$, and $\mathrm{MS}$ can be obtained by considering only the positive cultures from the urethra in men and the positive cultures from the cervix in women.

If we define relative resistance to penicillin for the strains investigated by us as $\mathrm{MIC} \geqq 0.08 \mu \mathrm{g} . / \mathrm{ml}$. comparison of our data with those of other Dutch authors gives the following picture (Table VIII, overleaf).

The percentage of strains relatively resistant to penicillin has not changed appreciably in recent years among the civilian population. In general, the percentages among seafaring personnel are more difficult to interpret as these patients form a less

TABLE III Contribution to detection of gonorrhoea in our series from cultures taken from sites other than urethra in men and cervix in women

\begin{tabular}{|c|c|c|c|c|c|}
\hline \multicolumn{4}{|c|}{ Positive cultures } & \multirow{2}{*}{$\begin{array}{r}M C \\
277 \\
1 \\
9 \\
1\end{array}$} & \multirow{2}{*}{$\begin{array}{r}M S \\
137 \\
0 \\
\mathbf{4} \\
0\end{array}$} \\
\hline $\begin{array}{l}\mathbf{U}+ \\
\mathbf{U}- \\
\mathbf{U}- \\
\mathbf{U}-\end{array}$ & $\begin{array}{l}\mathbf{P}+ \\
\mathbf{P}- \\
\mathbf{P}-\end{array}$ & $\begin{array}{l}\mathbf{R}+ \\
\mathbf{R}-\end{array}$ & $\mathbf{T}+$ & & \\
\hline \multicolumn{3}{|c|}{ Total patients } & & 288 & 141 \\
\hline
\end{tabular}

\begin{tabular}{|c|c|c|c|c|c|}
\hline \multicolumn{5}{|c|}{ Positive cultures } & $\frac{F C}{183}$ \\
\hline $\begin{array}{l}\mathbf{C}+ \\
\mathbf{C}- \\
\mathbf{C}- \\
\mathbf{C}- \\
\mathbf{C}-\end{array}$ & $\begin{array}{l}\mathbf{U}+ \\
\mathbf{U}- \\
\mathbf{U}- \\
\mathbf{U}-\end{array}$ & $\begin{array}{l}\mathbf{R}+ \\
\mathbf{R}- \\
\mathbf{R}-\end{array}$ & $\begin{array}{l}\mathrm{V}+ \\
\mathrm{v}-\end{array}$ & $\mathbf{T}+$ & $\begin{array}{r}183 \\
3 \\
5 \\
0 \\
0\end{array}$ \\
\hline \multicolumn{5}{|c|}{ Total patients } & 191 \\
\hline
\end{tabular}

TABLE IV Correlation of MICs for penicillin and ampicillin in MCU (male civilians-urethra) strains

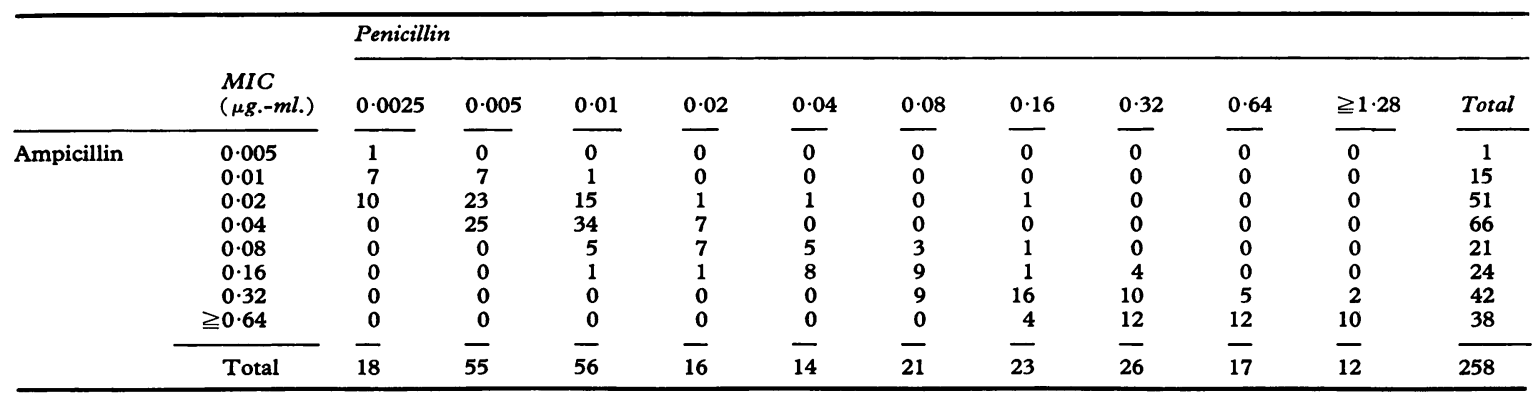

$r=$ Rank correlation coefficient $=0.89821$ 
TABLE V Correlation of MICs for tetracycline and ampicillin in MCU (male civilians-urethra) strains

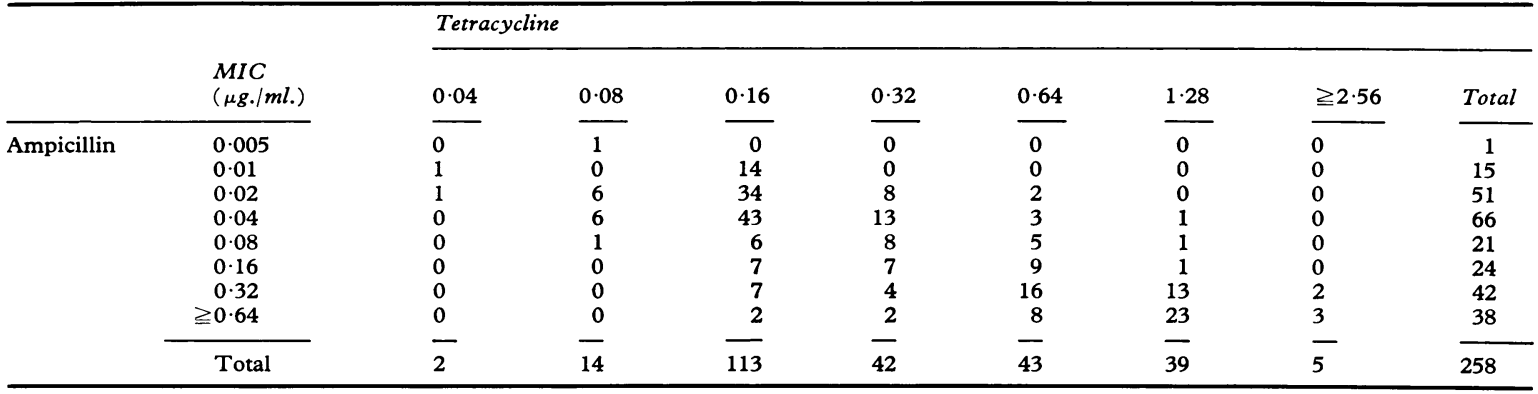

$r=$ Rank correlation coefficient $=0 \cdot 71155$

TABLE VI Correlation of MICs for tetracycline and penicillin in MCU (male civilians-urethra) strains

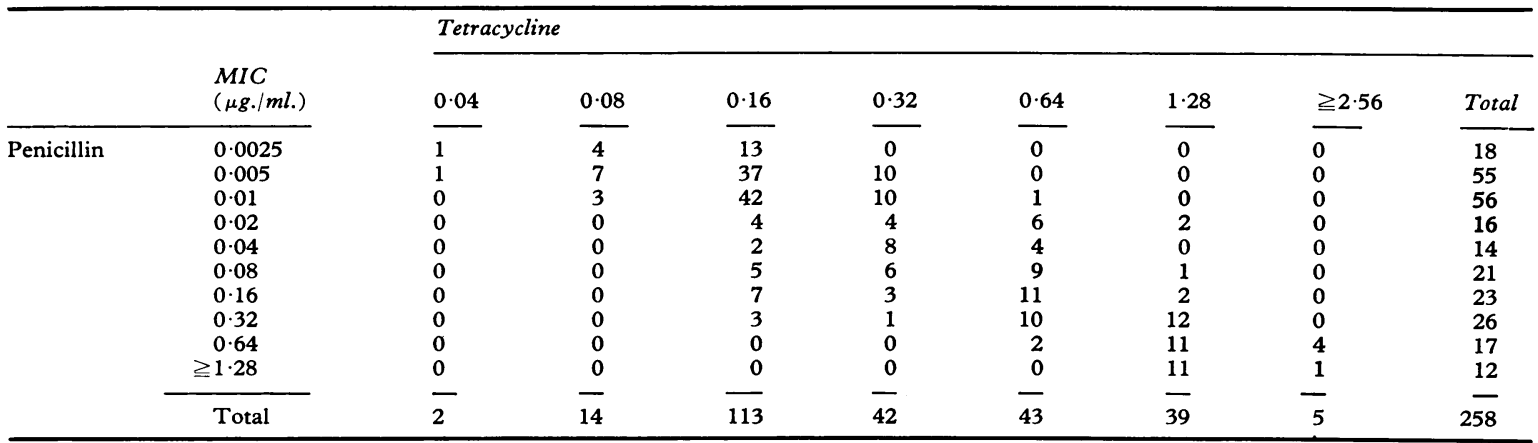

$r=$ Rank correlation coefficient $=0.77159$

TABLE VII Coefficients of rank correlation between MICs for penicillin and ampicillin, tetracycline and ampicillin, and tetracycline and penicillin in the gonococcal strains $M C U$ (male civilians-urethra), FCC (female civilians-cervix), and MSU (male seafaring personnel-urethra)

\begin{tabular}{|c|c|c|c|}
\hline \multirow[t]{2}{*}{ Antibiotics } & \multicolumn{3}{|l|}{ Patients } \\
\hline & $M C U$ & $F C C$ & $M S U$ \\
\hline Penicillin-ampicillin & 0.89821 & 0.88296 & 0.83959 \\
\hline $\begin{array}{l}\text { Tetracycline- } \\
\text { ampicillin }\end{array}$ & 0.71155 & 0.60167 & 0.65547 \\
\hline $\begin{array}{l}\text { Tetracycline- } \\
\text { penicillin }\end{array}$ & 0.77159 & 0.67219 & 0.79328 \\
\hline
\end{tabular}

homogeneous group in comparison to civilians. However, when the figures here are considered, there is no real evidence of an increase in the percentage of strains relatively resistant to penicillin in the MS group.

Our percentages of relatively resistant $\mathrm{MC}$ and FC strains are very similar to those found by Lynn, Nicol, Ridley, Rimmer, Symonds, and Warren,
(1970) and Leigh, Le Franc, and Turnbull (1969) in London, and by Gundersen, Ødegaard, and Gjessing (1969) in Norway, viz. 35, 39, and 34.5 per cent. respectively (relative resistance defined as MIC $\geqq$ $0.05 \mu \mathrm{g} . / \mathrm{ml}$. by Lynn and others, $\geqq 0.06 \mu \mathrm{g} . / \mathrm{ml}$. by Leigh and others, and $\geqq 0.075 \mu \mathrm{g} . / \mathrm{ml}$. by Gundersen and others).

If we define relative resistance to tetracycline $\mathrm{HCl}$ for the strains investigated by us as $M I C \geqq 1.28$ $\mu \mathrm{g} . / \mathrm{ml}$., we find that 17 per cent. of the MC, $12 \cdot 2$ per cent. of the FC, and 38.8 per cent. of the MS strains are relatively resistant. In the Netherlands, Heimans (1967) found that 14 per cent. of his FC strains were relatively resistant to tetracycline (MIC $\geqq 1.00$ $\mu \mathrm{g} . / \mathrm{ml}$.); this result agrees very closely with ours.

If we define relative resistance to ampicillin for the strains investigated by us as $\mathrm{MIC} \geqq 0.16 \mu \mathrm{g} . / \mathrm{ml}$., then 40.3 per cent. of the MC, 34.8 per cent. of the FC, and 68.6 per cent. of the MS strains are relatively resistant. The agreement between these percentages and those found for strains relatively resistant to penicillin is striking.

The correlation between the pairs of antibiotics, expressed in terms of the rank correlation coefficient 
TABLE VII Comparison of percentages of relatively resistant strains to penicillin isolated from male civilians $(M C)$, female civilians $(F C)$, and male seafaring personnel (MS), with percentages reported by other Dutch workers

\begin{tabular}{|c|c|c|c|c|c|c|}
\hline \multirow{2}{*}{ Authors } & \multirow{2}{*}{ Town } & \multirow{2}{*}{$\begin{array}{l}\text { Year } \\
\text { of report }\end{array}$} & \multicolumn{3}{|c|}{ Percentage relatively resistant to penicillin } & \multirow[b]{2}{*}{ Criterion } \\
\hline & & & $M C$ & $F C$ & $M S$ & \\
\hline $\begin{array}{l}\text { Vermeer and Schaap } \\
\text { Heimans } \\
\text { Wols-van der Wielen } \\
\text { Present study }\end{array}$ & $\begin{array}{l}\text { Amsterdam } \\
\text { Amsterdam } \\
\text { Rotterdam } \\
\text { Rotterdam }\end{array}$ & $\begin{array}{l}1962 \\
1967 \\
1971 \\
1974\end{array}$ & $\begin{array}{l}35 \cdot 0 \\
38 \cdot 4\end{array}$ & $\begin{array}{l}37 \cdot 0 \\
35 \cdot 0 \\
34 \cdot 9\end{array}$ & $\begin{array}{l}57 \cdot 0 \\
78.2 \\
70 \cdot 0 \\
67 \cdot 2\end{array}$ & 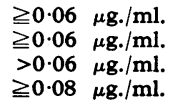 \\
\hline
\end{tabular}

$r$ for the MCU, FCC, and MSU groups of gonococci (Table VII), was found to be consistently highest for penicillin-ampicillin, and consistently lowest for tetracycline-ampicillin.

The correlation between the sensitivities of gonococci for tetracycline and penicillin has been described previously. Reyn and Bentzon (1968) stated that they had always found a positive correlation between tetracycline and penicillin. In the Netherlands, Heimans (1967) pointed out that there was a marked positive correlation between strains relatively resistant to penicillin and tetracycline. Verhagen, van der Ham, Heimans, Kranendonk, and Maina (1971) found a highly positive correlation between sensitivities to penicillin and tetracycline in 736 strains isolated in Kenya $(\mathrm{P}<0.01 ; r=0.7273)$.

A positive correlation between the sensitivities for penicillin and ampicillin has also been described previously, e.g. by Reyn and Bentzon (1968) and Jokipii and Renkonen (1970). Ødegaard (1962), Reyn and Bentzon (1968), and Jokipii and Rekonen (1970) showed that penicillin $G$ was more effective in vitro than ampicillin for the sensitive strains, while the reverse was found for the relatively resistant strains. This pattern was also found in our series (Table IV).

The positive correlation between tetracycline and ampicillin would be expected on the basis of the two correlations mentioned above.

\section{Summary}

In the period between October 18, 1971, and July 1, 1972, quantitative sensitivity determinations for ampicillin, penicillin, and tetracycline were carried out on gonococcal strains isolated in the outpatient department for Dermatology and Venereal Diseases of the University Hospital, Rotterdam. MIC distributions are given for 959 strains isolated from the urethra, prostatic fluid, rectum or tonsils/oropharynx in men, and from the cervix, urethra, rectum, vagina or tonsils/oropharynx in women.

The patients consisted of male and female civilians
(MC and FC) and male and female seafaring personnel (MS and FS).

A representative picture of the MIC distributions for ampicillin, penicillin, and tetracycline in the largest patient groups (MC, FC, and MS) could be obtained by considering only the strains from the urethra in men and the cervix in women. In total, 258 urethral strains from male civilians (MC), 172 cervical strains from female civilians (FC), and 134 urethral strains from male seafaring personnel (MS) were tested for sensitivity.

40.3 per cent. of the MC, 34.8 per cent. of the FC, and 68.6 per cent. of the MS strains were relatively resistant to ampicillin (MIC $\geqq 0.16 \mu \mathrm{g} . / \mathrm{ml}$.).

38.4 per cent. of the MC, 34.9 per cent. of the FC, and 67.2 per cent. of the MS strains were relatively resistant to penicillin ( $M I C \geqq 0.08 \mu \mathrm{g} . / \mathrm{ml}$.).

17 per cent. of the MC, $12 \cdot 2$ per cent. of the FC, and 38.8 per cent. of the MS strains were relatively resistant to tetracycline (MIC $\geqq 1.28 \mu \mathrm{g} . / \mathrm{ml}$.).

Statistical analysis showed a strong positive rank correlation between the sensitivities to the three antibiotics.

We wish to thank Mrs. M. P. E. de Jonge-Suy, Mrs. S. de Weerdt-van Ameyden, and Mr. H. D. Bruning for their technical assistance.

\section{References}

BAKker, P. G., Esseveld, H., and LeikeR, D. L. (1960) Ned. T. Geneesk., 104, 65

Ericsson, H. M., and SHERRIS, J. C. (1971) Acta path. microbiol. scand., Section B 1971, Suppl. 217

Gundersen, T., ØDegaARD, K., and GJessing, H. C. (1969) Brit. F. vener. Dis., 45, 235

Heimans, A. L. (1967) 'Diagnosis and Treatment of Gonorrhoea in Women' (Thesis).

JokIPII, A. M. M., and ReNkonen, O. V. (1970) Chemotherapy, 15, 317

Leigh, D. A., Le Franc, J., and Turnbull, A. R. (1969) Brit. $\mathcal{F}$. vener. Dis., 45, 151

LynN, R., Nicol, C. S., RIdley, M., Rimmer, D., SYMONDS, M. A. E., and WARREN, C. (1970) Ibid., 46, 404

ØDEGAARD, K. (1962) T. norske Laegeforen., 82, 55 
Reyn, A., and Bentzon, M. W. (1968) Brit. F. vener. Dis., 44, 140

Thayer, J. D., and Martin, J. E. (1966) Publ. Hlth Rep. (Wash.), 81, 559

Verhagen, A. R., van der Ham, M., Heimans, A. L., KRANENDONK, O., and MaINA, A. N. (1971) Bull. Wld Hlth Org., 45, 707

Vermeer, D. J. H., and SchaAp, G. J. P. (1962) Ned. T. Geneesk., 106, 1025

Wols-van DER WIELEN, A. (1971) Brit. F. vener. Dis., 47, 190

\section{Sensibilité des gonococoques à l'ampicilline, à la pénicilline et à la tétracycline à Rotterdam}

\section{SOMMAIRF}

Du 18 Octobre 1971 au 1 Juillet 1972, on détermina la sensibilité quantitative vis-à-vis de l'ampicilline, de la pénicilline et de la tétracycline sur des souches de gonocoques isolées au Département des malades externes de Dermatologie et de Vénéréologie de l'Hôpital Universitaire de Rotterdam. On indique le classement des CMI pour 959 souches isolées de l'urètre, du liquide prostatique, du rectum, ou des amygdales/de l'oro-pharynx chez les hommes, et du col utérin, de l'urètre, du rectum, du vagin ou des amygdales/de l'oro-pharynx, chez les femmes.

Les malades étaient des civils, hommes et femmes (MC et FC), et des hommes et femmes appartenant au personnel maritime (MS et FS).

On peut avoir une image représentative des répartitions des CMI dans les groupes les plus importants (MC, FC et MS) en prenant seulement en considération les souches isolées de l'urètre masculin et du col utérin. Au total, 258 souches urétrales provenant de civils masculins (MC), 172 souches cervicales de femmes civiles (FC) et 134 souches urétrales d'hommes du personnel maritime (MS) furent étudiées pour leur sensibilité.

40,3 pour cent des souches des MC, 34,8 pour cent des souches des FC et 68,6 pour cent des souches des MS furent relativement résistantes à l'ampicilline $(\mathrm{CMI} \geqslant 0,16 \mu \mathrm{g} . / \mathrm{ml}$.).

38,4 pour cent des souches des MC, 34,9 pour cent des souches des FC et 67,2 pour cent des souches des MS furent relativement résistantes à la pénicilline $(\mathrm{CMI} \geqslant$ $0,08 \mu \mathrm{g} . / \mathrm{ml}$.).

17 pour cent des souches des MC, 12,2 pour cent des souches des FC et 38,8 pour cent des souches des MS furent relativement résistant à la tétracycline $(\mathrm{CMI} \geqslant$ $1,28 \mu \mathrm{g} . / \mathrm{ml}$.).

L'analyse statistique a montré une corrélation positive de haut degré entre la sensibilité aux trois antibiotiques. 